\title{
Post Polymerisation Hypercrosslinking with Emulsion Templating for Hierarchical and Multi-Level Porous Polymers
}

\author{
Amadeja Koler, ${ }^{1}$ Irena Pulko ${ }^{2}$ and Peter Krajnc ${ }^{1, \star}$ \\ ${ }^{1}$ University of Maribor, Faculty of Chemistry and Chemical Engineering, PolyOrgLab, Smetanova 17, Maribor, Slovenia \\ ${ }^{2}$ Faculty of Polymer Technology, Ozare 19, Slovenj Gradec, Slovenia \\ *Corresponding author: E-mail:peter.krajnc@um.si
}

Received: 02-11-2020

\begin{abstract}
Porosity in polymers and polymeric materials adds to their functionality due to achieving the desired tailored characteristics porosity offers, such as improved mass transfer through the material, improved accessibility of reactive sites, reduced overall mass, tunable separation properties, etc. Therefore, applications in many fields, e.g. catalysis, separation, solid phase synthesis, adsorption, sensing, biomedical devices etc., drive the development of polymers with controlled morphology in terms of pore size, shape, interconnectivity and pore size distribution. Of particular interest are polymers with distinct bimodal or hierarchical pore distribution as this enables uses in applications where pore sizes on multiple levels are needed. Emulsion templating can be used for the preparation of polymers with included interconnected spherical pores on the micrometre level while post polymerisation crosslinking adds micro porosity. Combined use of both techniques yields multi-level and hierarchically porous materials with great application potential.
\end{abstract}

Keywords: PolyHIPE; hypercrosslinking; porous polymers; porosity; emulsion templating; hierarchical polymers

\section{Introduction}

Methods for generation of porosity in polymers can be generally divided into chemical and physical. Among physical methods, various templating can be used while post polymerisation crosslinking and phase separation induced syneresis are examples of chemical methods (Figure 1). According to IUPAC guidelines, ${ }^{1}$ pores are referred to as macro (diameters over $50 \mathrm{~nm}$ ), meso (diameters between 2 and $50 \mathrm{~nm}$ ) and micro (diameters less than $2 \mathrm{~nm}$ ). In terms of pore size distribution, it can be statistical however materials with distinct bimodal or hierarchical pore distribution can be prepared meaning that micro and macro pores are present or that pore size distribution follows a hierarchical concept where a multi-level porous material is produced with pore size levels following one after another. Among templating methods, emulsion templating is widely used. ${ }^{2-7}$ Both water-in-oil and oil-in-water emulsions can be used for the purpose of macro porosity induction during the polymerisation process. When a high concentration of the droplet phase is used, droplets' shapes become distorted and a dispersion of droplet size is observed
(Figure 2). In the case of inclusion of monomers into the continuous phase the polymerisation results in a monolithic porous material, typically with an interconnected porosity which is the result of the shrinkage of continuous phase volume at the sol-gel transition. In the case of uniform packing of monodisperse spherical droplets, the volume of the droplet phase accounts for $74,05 \%$ of the total emulsion volume while at random packing this share is lower, namely $64 \%{ }^{8}$ Polymers prepared from emulsions with droplet phase volume shares higher than these border values are termed polyHIPEs, following the abbreviation for high internal phase emulsion. ${ }^{9}$ The internal topology of so prepared polymeric material features two levels of pores, the primary pores, termed cavities and secondary, interconnecting pores (Figure 3). The size of primary pores follows the size of the droplets prior to polymerisation as demonstrated by a series of experiments containing emulsion aging and room temperature polymerisation initiation with a redox initiation pair. ${ }^{10}$ Therefore, the control of emulsion droplet size prior to polymerisation is the main control also for the primary pore size. The main factors controlling emulsion droplet size include emulsion 


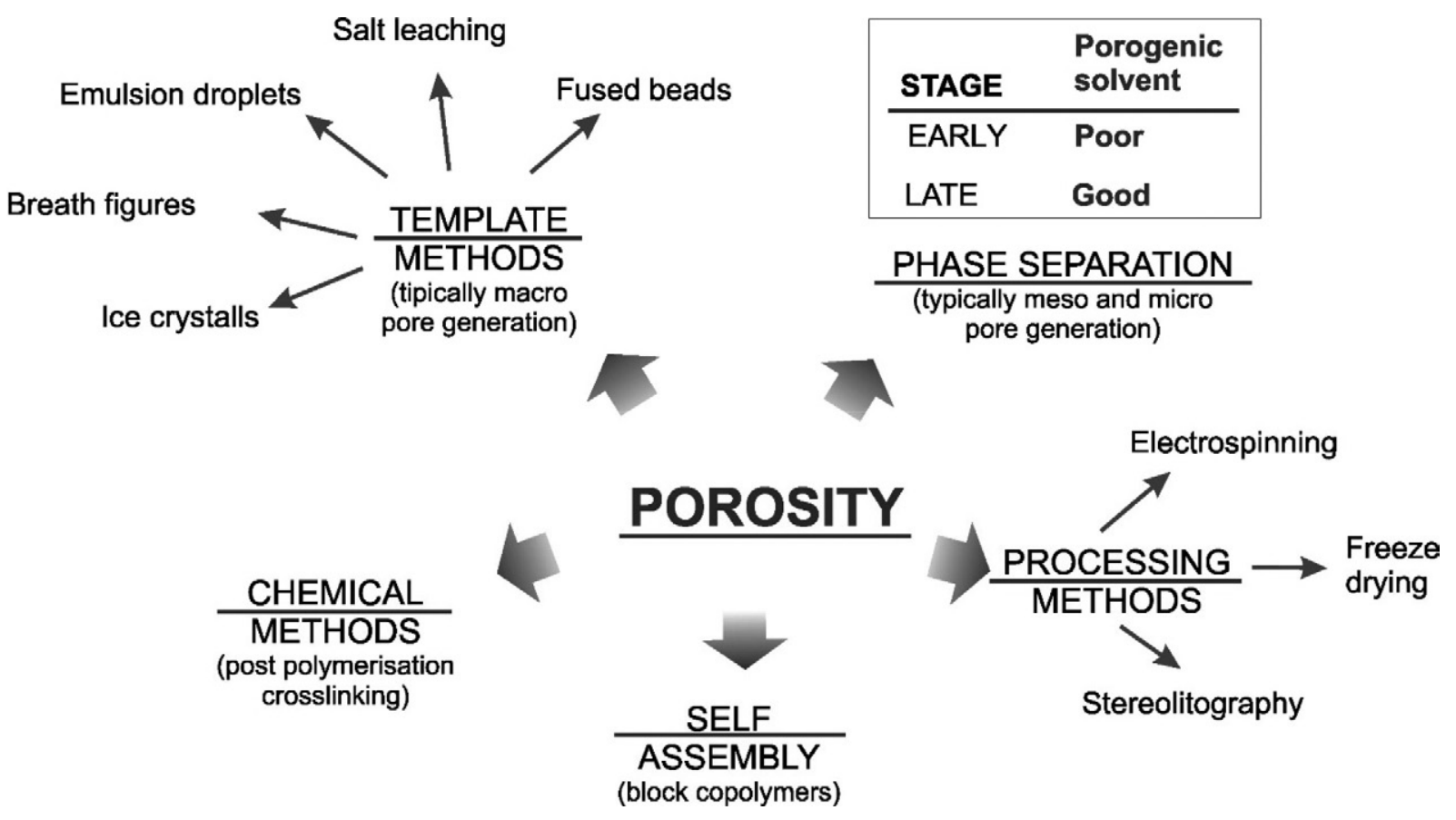

Figure 1: Methods for porosity creation in polymers

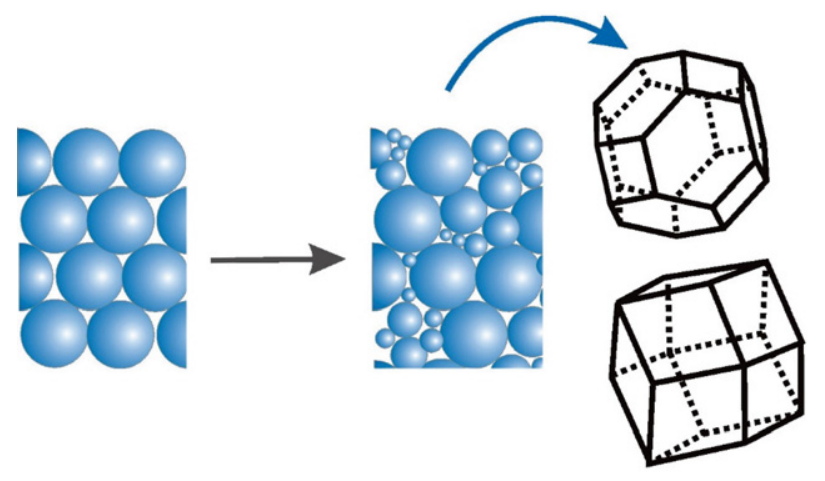

Figure 2: Droplet size and shape change at emulsion concentration

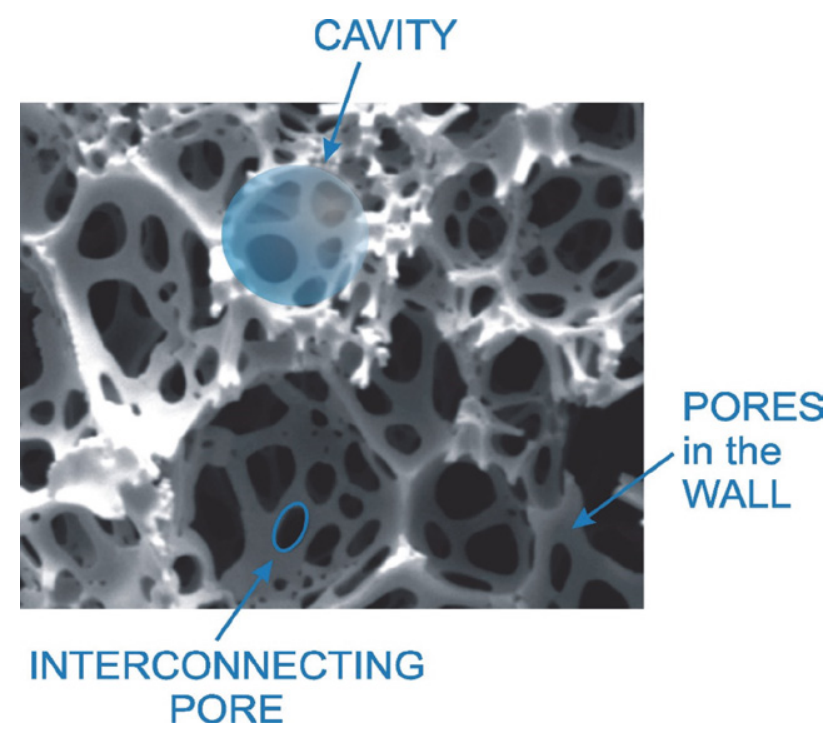

Figure 3: PolyHIPE morphology stabilization by surfactant molecules and energy input at emulsion preparation.

On the other hand, the frequency and size of interconnecting pores determine the connectivity of porous structure or what could be defined as the openness of the structure (Figure 4). ${ }^{11}$
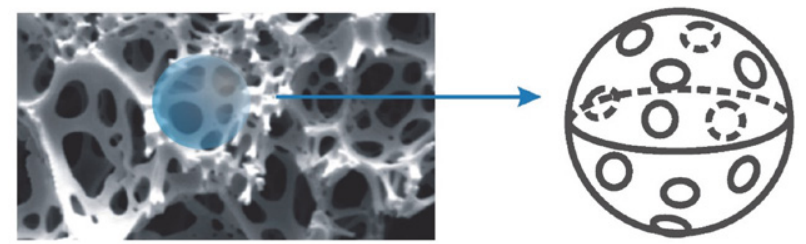

$$
\mathrm{O}=\frac{\text { Open surface of cavity }}{\text { Surface of cavity }}=\frac{S_{\mathrm{O}}}{S_{\mathrm{C}}}
$$

Figure 4: Interconnectivity of porous structure in polyHIPEs

The thickness of the film of continuous phase between the adjacent droplets seems to be the main factor affecting the size and frequency of the interconnecting pores. This is mainly determined by the droplet to continuous phase volume ratio and by the concentration and structure of the surfactant(s). In summary, main factors determining the morphological features of polyHIPEs are volume ratio of droplet/continuous phase, energy input at preparation, and surfactant concentration and structure. Many other variables were considered and their role can be important. This makes a polymerizable HIPE a multi variable system and careful experimental consideration must be involved when planning a particular structure (Figure 5, Table 1). 
Table 1: Experimental factors and their effect on HIPE stability and polyHIPE morphology

\begin{tabular}{lll}
\hline Experimental factor & Effect on HIPE stability & Effect of polyHIPE morphology \\
\hline Rate of stirring & Higher rates-increase in stability & Smaller cavities \\
Time of stirring & Prolonged stirring-increase in stability & Reduced dispersion of cavities \\
Viscosity & Increase in viscosity-increase in stability & Smaller cavities \\
Surfactant content & Lowers the interfacial tension & Increase in interconnectivity \\
Temperature & Increase in temperature-enhances the coalescence, & Increase in cavity size, increased \\
& reduces stability & dispersion. \\
stabilizing salts & Enhance the rigidity of the interfacial film-enhances stability. & Reduces cavity size \\
& Inhibiting Ostwald ripening. & \\
\hline
\end{tabular}

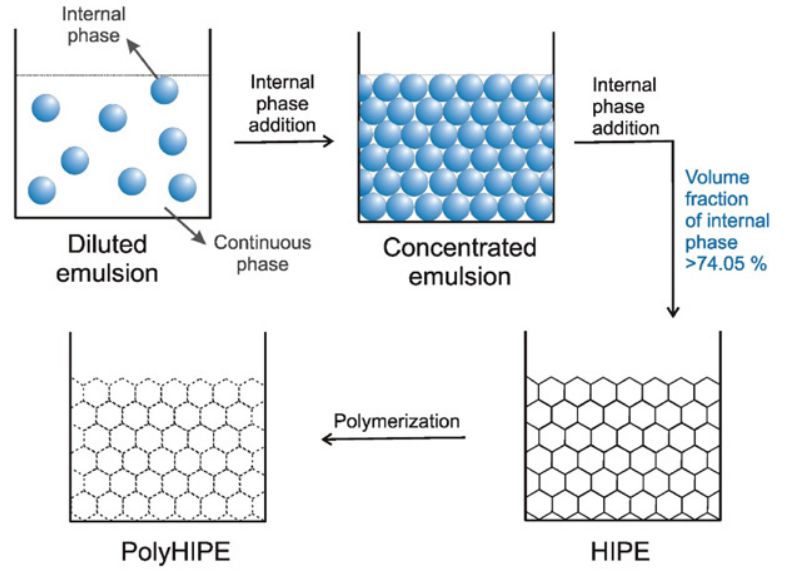

Figure 5: polyHIPE preparation

\section{Recent Advances in PolyHIPE Synthesis and Creation of Multi-Level Porosity}

While water-in-oil high internal phase emulsions are most commonly used for the preparation of polyHIPE polymers, other emulsion based systems have also been described. Both oil-in-water and oil-in-oil high internal phase emulsions can be applied. ${ }^{12}$ For water soluble or hydrophilic monomers, solvents such as hydrocarbons or benzene derivatives were used as the droplet phase. In such manner, polyHIPEs were prepared from acrylic acid, ${ }^{13}$ 2-hydroxyethyl methacrylate, ${ }^{14-18} \mathrm{~N}$-isopropyl acrylamide (NiPAAm), ${ }^{19,20}$ acrylamide, ${ }^{21}$ 1-vinyl-5-aminotetrazole, ${ }^{22,23}$ and dimethylaminoethyl methacrylate. ${ }^{24}$

Furthermore, combination of emulsion templating and other porosity induction techniques, have yielded hierarchically porous polymer materials. Sušec et al. ${ }^{25}$ and Johnson et al. ${ }^{26}$ have demonstrated the principle of applying a high internal phase emulsion within a stereophotolithographic based additive manufacturing setup. With such a system, a three-dimensional object can be built using a lithographic photo polymerizable system. Due to the use of a high internal phase emulsion with photo polymerizable monomers in the continuous phase, the object has an internal polyHIPE structure. Thus, another level of po- rosity is created using the lithographic process while pores of smaller dimensions are created as a result of emulsion templating. Monomer mixtures particularly suitable for such photo polymerisation were found to be multifunctional thiols and alkenes producing polymer networks via the thiol-ene click reaction. ${ }^{27}$

Another recent example of adding structure complexity is the use of hard sphere templating. Within this approach, spherical particles (typically polymeric) are fused together, to construct a monolithic porous network with interconnected porosity. So constructed material is then impregnated with a monomer mixture, polymerized while the previously constructed template dissolved. Macroporous polymethacrylates prepared in this way have open interconnected porosity and have been used as scaffolds in tissue engineering applications. ${ }^{28-31}$ We have shown that a combination of this hard sphere templating and high internal phase emulsion templating can yield polymers with open interconnected and hierarchical porosity which is especially advantageous in biomedical applications such as tissue constructs. ${ }^{32}$ Primary monolithic template was formed by sintering polymethyl methacrylate beads and subsequently filled with a high internal phase emulsion containing thiols and alkenes as monomers in the continuous phase (Figure 6). Photopolymerisation yielded hierarchically structured polymer network with open porosity and biodegradability was introduced by the use of thiol monomers with ester groups. (Figure 7) So prepared multi-level porous polymers were successfully applied as scaffolds for human bone cell growth.

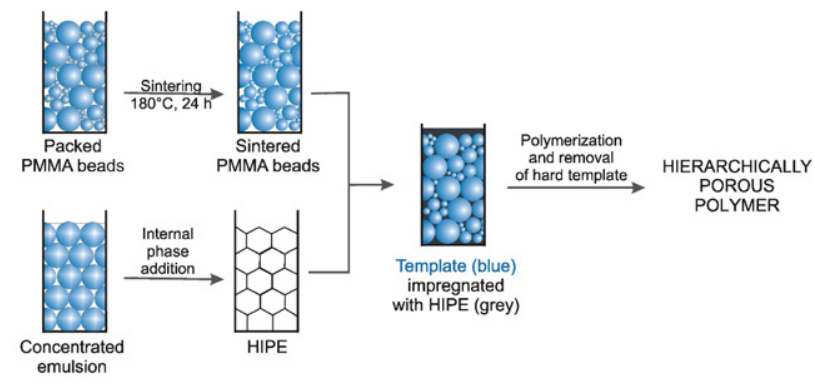

Figure 6: Combination of hard sphere and emulsion templating 


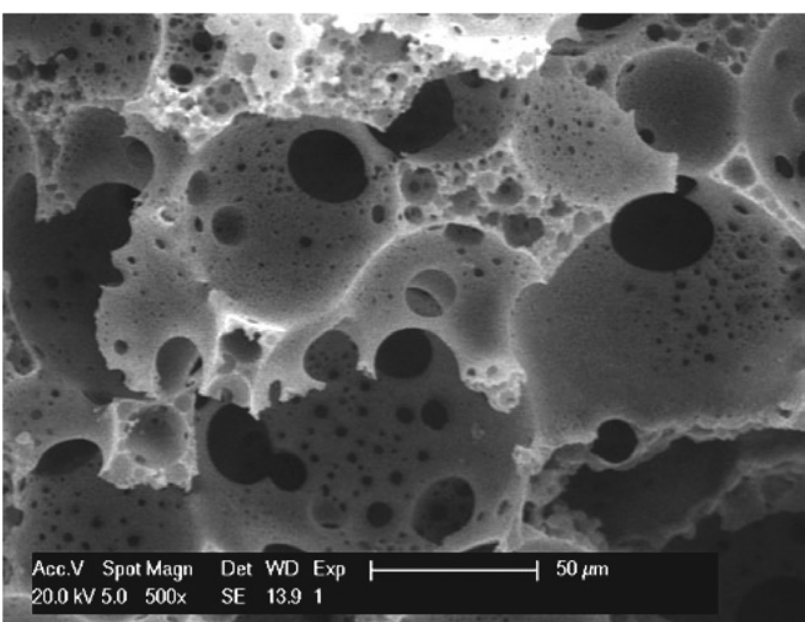

Figure 7: Scanning electron micrograph of hierarchically porous polymer prepared by combining hard sphere and emulsion templating

While electrospinning is in itself a method producing porous fibrous structures from polymer solutions or melts, ${ }^{33,34}$ high internal phase emulsion templating has been used in combination with electrospinning to add a level of porosity to the product. ${ }^{35,36}$ Using this combination, fibres with bicontinuous morphology were obtained by electrospinning HIPEs consisting of aqueous poly(vinyl alcohol) solutions dispersed within polycaprolactone-in-toluene solutions. ${ }^{35}$ Similarly, Dikici et al. ${ }^{36}$ used a polycaprolactone barrier membranes to form bilayers by combining electrospinning and emulsion templating techniques and applied them for guided bone regeneration. The electrospunn fibres had a mixture of open and closed cell porous polyHIPE type morphology.

\section{Inducing Meso and Micro Porosity Within PolyHIPEs}

Due to relatively large pores induced by the droplet phase in polyHIPE preparation, the result is a macroporous material with primary pore sizes typically between 500 $\mathrm{nm}$ and $100 \mu \mathrm{m}$. Consequently, specific surface areas of polyHIPEs are low, usually below $50 \mathrm{~m}^{2} / \mathrm{g}$. This is the result of the lack of meso and micro porosity. For many applications surface area of the polymer support plays a vital role. Early attempts of improving specific surface areas of polyHIPEs mostly included the addition of porogenic solvents to the monomer containing continuous phase ${ }^{37}$ and increasing the crosslinking degree ${ }^{38}$ thus producing polyHIPEs with specific surface areas up to $550 \mathrm{~m}^{2} / \mathrm{g}$. Introduction of porogenic solvent into the monomer containing continuous phase induces meso porosity via either early or late phase separation within the gelation process during the polymerisation. ${ }^{39}$ Surfactant concentration and structure also affect the surface area of styrene based poly-
HIPEs. ${ }^{40}$ However, both methods, namely adding porogenic solvent and surfactant to the monomer containing continuous phase increase the nominal porosity which results in sacrificing the material mechanical properties in terms of elastic modulus and brittleness. The morphology of polymers prepared by the addition of porogenic solvents include a fused-bead, cauliflower-like features which is not optimal for mechanical properties. ${ }^{39}$ Our study comparing materials with fused-bead and polyHIPE morphology showed that polyHIPE structure is superior to fused-bead morphology allowing for the preparation of materials with overall porosities higher than $75 \% .{ }^{32} \mathrm{Com}$ bining high porosity with sufficient mechanical stability is an important materials feature with applications in mind. For example, permeable open cellular polyHIPEs for chromatography stationary phases and membranes with significantly higher porosity compared to commercially available monolithic columns facilitate lower back pressures and thus the efficiency of separation. ${ }^{41-50}$

\section{Post Polymerisation Crosslinking}

In order to avoid the formation of fused bead type morphology within the formulating polymer film of the continuous phase of a high internal phase emulsion, a post polymerisation crosslinking of already formed polyHIPE material can be attempted.

Post polymerisation crosslinking, in this description referred to as hypercrosslinking, is a method of polymer chain crosslinking and the result is the creation of numerous new pores at meso and micro size scale and thus the creation of meso and/or microporous polymer material. ${ }^{51,52}$ The porous profile of hypercrosslinked polymers differs from the porous profile of polymers prepared by free radical polymerisation of monomers and crosslinkers. The porosity of polymers prepared by conventional copolymerisation is the result of phase separation during polymerisation in the presence of an inert diluent, which may be either a non-solvent or a thermodynamically good solvent. The non-solvent does not dissolve the growing crosslinked chains, so the network shrinks and precipitates into micro spheres. These non-porous nodules aggregate and agglomerate in a cauliflower-like structure, and the prepared material is macroporous. ${ }^{53-55}$ When a good solvent is used, the polymer network swells, but at high crosslinking degrees it can no longer adsorb the diluent. This results in phase separation in the form of micro and macrosyneresis. ${ }^{56}$ In the case of macrosyneresis, a macro porous network is formed as the resulting gel decomposes and thus a microgel is formed, which behaves as a continuous phase in the reaction mixture. These particles then agglomerate during the polymerisation to form a macroporous network. While in microsyneresis the diluent is distributed over the gel. The result of the whole texture is a macroporous network with cauliflower-like structure, but 
having micro pores due to the primary polymer nodules. ${ }^{53-55}$ By using a diluent during radical crosslinking even in the continuous phase of high internal phase emulsions, macroporous materials are obtained. Microsyneresis also introduces micro pores, thus influencing the increase of specific surface area. However, frequently, due to strong capillary forces, the micro pores in polyHIPE collapse during solvent removal.

Unlike traditional crosslinking polymerisation, hypercrosslinked polymers are prepared by post polymerisation crosslinking of long polymer chains in a semi-solution state creating many new bridges. This does not result in phase separation because the polymer chains are distributed throughout the solution and are strongly solvated throughout the hypercrosslinking. A typical example of such process is heating of solvated chloromethylated polystyrene in the presence of a Friedel-Crafts catalyst. This creates new connections by converting chloromethyl groups into methylene bridges that interconnect polymer chains. When the swelling solvent is removed by drying, the additional crosslinking prevents complete collapse of the polymer network and the resulting polymers exhibit extensive microporosity even in the dry state. Initially, the formation of methylene bridges is fast because the mobility of the polymer chains in the swollen polymer is higher than later in the reaction, when the polymer chains are already connected to the newly formed methylene bridges. By introducing new methylene bridges into the network, pores are formed as spaces between highly cross-linked nodules. In further stages of hypercrosslinking, the rigidity of the nodules increases and therefore, after solvent removal, the morphology results in a stable microporous network. ${ }^{52,57}$ Hypercrosslinked polymers prepared from gel-type precursors contain only the micro pores. If, on the other hand macroporous polymer is used as the precursor, the product then contains beside the macro pores also micro pores, and a polymer with a bimodal pore distribution is formed. Hypercrosslinked polymers contain a very high density of crosslinks creating micro pores and exhibit high surface areas up to $2000 \mathrm{~m}^{2} / \mathrm{g} .{ }^{58,59}$ After the removal of the solvent, micro pores remain, which increases compatibility with both polar and non-polar solvents, ${ }^{60,61}$ what is extremely important for applications. The chemical nature of the conventionally prepared STY/DVB polymer is very similar to the hypercrosslinked polymers that have many methylene bridges between polymer chains. However, these materials differ crucially in terms of topology and mechanical properties. STY / DVB copolymers are prepared without the addition of solvent, which means that their polymer chains are very densely packed in dry state, due to the strong attraction between them. Under these conditions, the polymers swell in thermodynamically good solvents, since the polymer-polymer interactions are replaced by stronger polymer-solvent interactions. Hypercrosslinked polymers, however, are prepared in the presence of an excess of good solvent, and if the crosslinking rate is high and conformational rigid connections are established, then the polymer chains are not densely packed after removal of the solvent. The final material in the dry state has high free volume and significantly reduced polymer-polymer interactions. It is essential that due to the affinity between the polymer fragments, the rigid structure of the hypercrosslinked polymer causes high inner stresses in the polymer chains of the network. Because of this, the hypercrosslinked materials tend to release inner stresses, which happens when the network is expanded, that is, when it swells. Swelling is possible on contacting any liquid, regardless of thermodynamic affinity with the polymer which means that the hypercrosslinked polymers are compatible with both thermodynamically good and bad solvents. ${ }^{60,62}$

Hypercrosslinking can be achieved by different chemical methods and can be divided into: post polymerisation crosslinking (hypercrosslinking using polystyrene precursors, hypercrosslinking using VBC / DVB precursors), direct one-step polycondensation of functional monomers and hypercrosslinking by the so called knitting method.

\section{1. Hypercrosslinking of Polystyrene Precursurs (Davankov Resins)}

Introduction of hypercrosslinking of polymer chains dates into 70's when hypercrosslinked polystyrene (PS) was demonstrated, using linear PS or gel-type swollen polystyrene-co-divinylbenzene and external crosslinkers in the presence of Lewis acid catalyst and solvents. ${ }^{63}$ External crosslinkers create new covalent bonds between polystyrene chains applying the Friedel-Crafts reaction ${ }^{61,64,65}$ (Scheme 1). This reaction achieves short and rigid connections and forms a rigid three-dimensional polymer network. Almost all aromatic rings can be consumed in this reaction, which results in a high degree of hypercrosslinking, and consequently in a large number of newly formed links and a high specific surface area of the materials. ${ }^{51}$ Typical protocol for hypercrosslinking of linear polystyrene or the STY / DVB copolymer contains introducing a sufficient amount of external crosslinker into the dissolved linear polystyrene or swollen polystyrene network and adding the Lewis acid while cooling the reaction medium to achieve homogeneous distribution of the catalyst before gelation of the mixture. The mixture is then heated, allowing high conversion of the reactive linker groups. ${ }^{66}$ As external linkers, chloroalkanes are most commonly used; usually dichloroethane, as it plays two roles - as an external linker and a good solvent for PS.

Chloromethyl ether was used predominantly for the hypercrosslinking of polystyrene, but was replaced by monochlorodimethyl ether, ${ }^{60,67-69}$ carbon tetrachloride $^{70,71}$ dichloroxylene, ${ }^{64,72} 4,4$ '-bis (chloromethyl)-biphenyl ${ }^{64,72}$ trifunctional tris-(chloromethyl)-mesitylene, ${ }^{51}$ 4,4'-bis-chloromethyl-1,4-diphenylbutane, ${ }^{51}$ formalde- 
hyde dimethyl acetal ${ }^{71-74}$ or dichloroethane $\mathrm{e}^{51,75,76}$ and other dichloroalkanes, ${ }^{76}$ due to its adverse health effects. It should be noted that the length of the external crosslinker affects the rigidity of the hypercrosslinked material, which also affects the morphology of the material. All the compounds form bridges of a limited conformational mobility in the final network except for diphenylbutane. In this case, the diphenylmethane crosslinker type are most influenced by the rigidity of the structure. Another limitation in mobility is tris-(chloromethyl)-mesitylene because it links three polystyrene chains at one point.

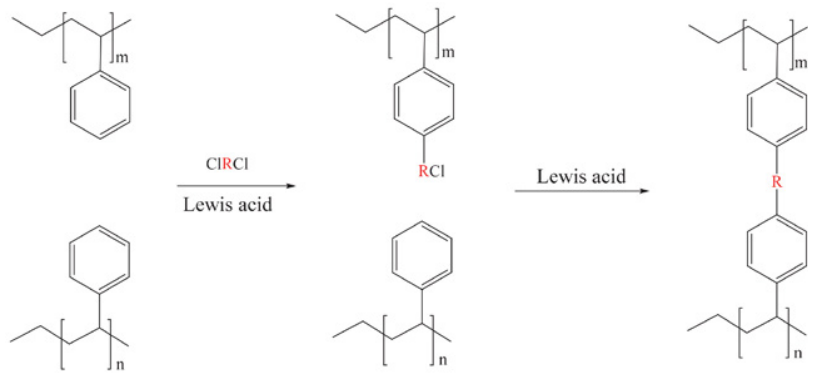

Scheme 1: Post polymerisation hypercrosslinking: Hypercrosslinking using polystyrene precursurs (Davankov resins)

When PS with a low degree of initial crosslinking $(0.3-2 \%)$ is used for hypercrosslinking, intrinsic microporosity is formed. However, if the initial degree of crosslinking is increased, the macroporous network is formed prior to hypercrosslinking, so the final pore distribution is bimodal. ${ }^{61,77}$

Due to their high surface area, good solvent compatibility and good mechanical properties, bimodal porosity and interpenetrating network, hypercrosslinked polystyrenes are often used as adsorbents for gases ${ }^{78,79}$ and various organic molecules, ${ }^{57,80,81}$ for chromatographic separation, ${ }^{82-84}$ or for adsorbents for blood purification. ${ }^{85}$

\section{2. Hypercrosslinking Using Chloromethylated Groups of Vinylbenzyl Chloride}

Hypercrosslinking can be performed on polyvinylbenzyl chloride or its copolymers utilizing vinylbenzyl chloride moieties in the polymer chains as internal electrophiles in the Friedel-Crafts reaction, without the addition of external linkers (Scheme 2). ${ }^{58,61}$ In this reaction, the chloromethyl groups are converted to methylene bridges and thus new links are created. The aromatic ring which is to be substituted is electron-rich, resulting in a formation of six-membered ring following the cyclization reaction. As with Davankov's type of hypercrosslinking, $\mathrm{FeCl}_{3}$ is most commonly used as a Friedel-Crafts catalyst because it has good solubility in the usual solvents used and does not cause steric hindrance. ${ }^{58}$ Due to the similarity of the polystyrene network to VBC / DVB network, the same solvents are used, most commonly DCE. The morphology of polymers hypercrosslinked by this post-polymerisation approach is similar to Davankov type resins meaning that hypercrosslinking induces micro pores and results in a significant increase of specific surface area. This was demonstrated by hypercrosslinking several poly (VBC-DVB) copolymers with DVB content between $2 \%$ and $20 \% .{ }^{58}$ The specific surface area of hypercrossliked products depended on the initial crosslinking and reaction time, being highest with lowest initial crosslinking and increasing with reaction time up to 2 hours while further elongation of reaction time had no effect. Decrease in the chloride content of the polymer coincides with the drastic increase in the specific surface area.

The importance of initial crosslinking for efficiency of hypercrosslinking and final porous structure was confirmed in another report. ${ }^{86}$ The maximum specific surface area was achieved after hypercrosslinking of polymer containing $2 \%$ of DVB $\left(2060 \mathrm{~m}^{2} / \mathrm{g}\right)$. By increasing the DVB amount, a bimodal structure was formed, with well-defined macro and micro pores, while at 7\% of DVB the structure was completely micro porous. Increasing the surface area after hypercrosslinking of VBC/DVB polymers at a lower DVB content occurs because the macromolecular chains of the polymer are still very loose and can orient more favorably in the presence of solvent in the hypercrosslinking process, thus forming more methylene bridges than in the case of higher crosslinked poly (VBC / DVB).

One of the most advantageous consequences of hypercrosslinking VBC / DVB polymers is their improved sorption properties. Unlike non-functionalized hypercrosslinked polystyrene, which is a good sorbent due to hydrophobic $\pi-\pi$ interactions, ${ }^{82}$ functional groups can undoubtedly improve the adsorption properties, which in turn can affect the development of many applications. ${ }^{87-91}$

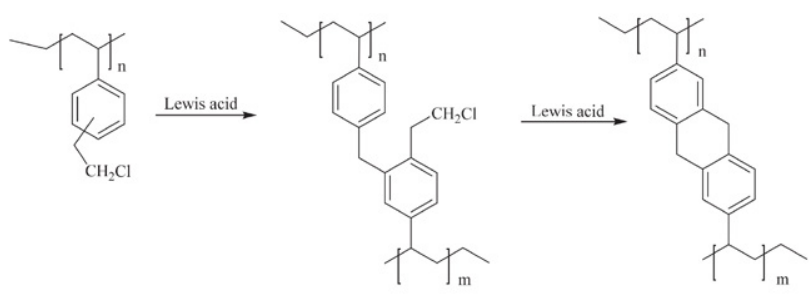

Scheme 2: Post polymerisation hypercrosslinking : Hypercrosslinking using chloromethylated groups of vinylbenzyl chloride

\section{3. Direct Hypercrosslinking Arising from Polycondensation}

Hypercrosslinked polymers can also be produced by the direct polycondensation of small molecule monomers without the need to make the precursor crosslinked polymer. However, the synthesis of polymer precursors is 
time-consuming and limited functional monomers can be selected to satisfy the combined conditions from reactions of radical polymerisation and Friedel-Crafts alkylation. Similarly to the other hypercrosslinking approaches, these use DCE as a solvent and $\mathrm{FeCl}_{3}$ as a Friedel-Crafts catalysts. The resulting networks can be considered the analogues of the Friedel-Crafts linked PS materials. This direct approach creates microporous organic networks and uses bis(chloromethyl) aromatic monomers such as dichloroxylene, ${ }^{92}$ bis(chloromethyl)biphenyl, ${ }^{75,93}$ and bis(chloromethyl) anthracene. ${ }^{75,93}$ By using Lewis acid as a catalyst, the chloromethylene groups react with adjacent phenyl rings. This results in the formation of rigid methylene bonds between the rings, which in turn produces micro pores and high specific surface areas up to $2000 \mathrm{~m}^{2} / \mathrm{g} .{ }^{93}$ Due to high specific surface areas hypercrosslinked polymers using polycondensation have good gas adsorption capacity. ${ }^{75,93-95}$ The use of $o$-DCX isomers for condensation with $m$-DCX or $p$-DCX has been found to have an adverse effect on the growth of specific surface areas, while $m$-DCX and $p$-DCX provide materials with comparable specific surface areas. ${ }^{75}$ For well-defined micro porous polymers, DCX and BCMBP were used as crosslinkers in order to connect heterocyclic (carbazole), metal-doped (ferrocene) and highly rigid (triptycene) building blocks. It was also found that the length of crosslinkers can affect the porosity of the resulting polymer. For example, longer crosslinker molecules affect larger pores, while shorter molecules create micro pores, thereby contributing to an increase in the specific surface area of the polymer. ${ }^{96}$ Fluorene derivatives (fluorene, 9,90-spirobi(fluorene), dibenzofuran and dibenzothiophene) were also used as non-functional aromatic precursors, which showed good microstructure in condensation with BCMBP under Friedel-Crafts catalytic conditions. The highest surface area of up to $1800 \mathrm{~m}^{2} / \mathrm{g}$ was obtained from dibenzofurane monomers with $10 \%$ molar fraction. ${ }^{95}$

Aromatic precursors used in addition to benzene ${ }^{97,98}$ were polyaniline, ${ }^{95}$ polypyrrole, ${ }^{94}$ polythiophene, polyfurane, aniline, carbazole, ${ }^{99,100}$ aminobenzene, ${ }^{101}$ bishydroxymethyl monomers, ${ }^{102}$ and were found to form hypercrosslinked polymers.

\section{4. Knitting Aromatic Compound Polymers Using an External Crosslinker}

A special type of one-step polycondensation, however, is the "knitting" method for hypercrosslinking with an external crosslinker-formaldehyde dimethyl acetal FDA, which is more environmentally friendly as it has no dangerous by-products during the Friedel-Crafts reaction. The mechanism of the reaction is proposed as: Lewis acid first complexes with the crosslinking molecule, which reduces the interaction between the methoxyl group and the central carbon atom, and then produces a large number of intermediate carbocations in the DCE (Scheme 3). ${ }^{98}$ The carbocations then react with the phenyl ring and the addition of the multi - methoxymethyl groups to the aromatic ring proceeds, releasing methanol. The methoxymethyl groups are then converted to methylene links and reacted with other phenyl rings to form a rigid crosslinked structure.

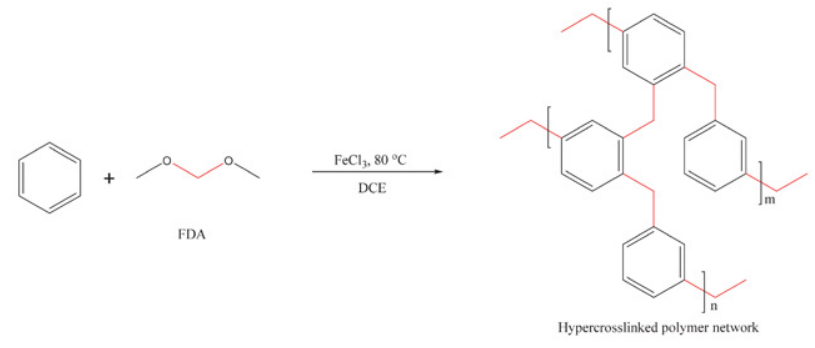

Scheme 3: Typical hypercrosslinking by the knitting method from benzene monomers ${ }^{98}$

Typically, in this one-step approach, the aromatic monomer (including benzene, phenol or chlorobenzene), the crosslinker (FDA) and the catalyst $\left(\mathrm{FeCl}_{3}\right)$ are dissolved in DCE to complete the condensation. ${ }^{98}$ Increasing the FDA crosslinker content of hypercrosslinked materials obtained using tetraphenylmethane blocks also increases the specific surface area up to $1314 \mathrm{~m}^{2} / \mathrm{g} .{ }^{103}$ Similar approaches using FDA as external crosslinker were shown with different monomers such as aromatic heterocycles, ${ }^{104,105}$ hydroxymethylated aromatic molecules, ${ }^{102}$ aniline and benzene, ${ }^{72,97}$ styrene ${ }^{105}$ and tetrahedral monomers, ${ }^{106,107}$ among others. The "knitting" method is used for the design and synthesis of microporous polymers based on various rigid aromatic building blocks, including nonhalogenated monomers. 1,4-dimethoxybenzene was also used as an external crosslinker. ${ }^{108}$

\section{Hypercrosslinking of PolyHIPEs}

Hypercrosslinking of polyHIPE polymers results in rigid polymers with induced meso and microporosity (tertiary pores) in macroporous material which leads to very high specific surface areas due to induction of micro and meso pores. Research so far shows that the morphology of polyHIPEs does not change significantly after hypercrosslinking and the typical open cellular macroporous structure is retained. ${ }^{59}$ Rigid connections created during hypercrosslinking make better compatibility with both thermodynamically good and bad solvents and thus better accessibility of reactive sites. As a result, hierarchically porous material is obtained with macro pores that allow convective transfer and reduce back pressure in flow systems, and at the same time with high specific surface area due to the presence of micro and meso pores allowing good accessibility of reactive sites. PolyHIPEs with hierarchical or 
bimodal porosity can be very useful in many applications as demonstrated by various research groups.

Schwab et al. ${ }^{77}$ synthesized VBC / DVB polyHIPE monoliths, and the DVB molar fraction varied between 2.5 and $40 \%$. Materials were hypercrosslinked by FriedelCrafts alkylation reaction in the presence of a Lewis base to give monoliths with specific surface areas up to 1200 $\mathrm{m}^{2} / \mathrm{g}$, while maintaining the morphology of precursor polyHIPE. Due to hypercrosslinking, the non-porous walls of polyHIPEs have become highly microporous. Such monolithic VBC based polyHIPE polymers with bimodal structure were proven to be very promising for n-butane storage and the results were comparable to the commercially available Sorbonorit powder. In another report, VBC based polyHIPEs with $2 \mathrm{~mol} \%$ DVB content were used for controlled hypercrosslinking to leave some unreacted benzyl chloride groups for further binding of methyl amino pyridine. Functionalized hypercrosslinked polyHIPE was used as a very effective nucleophilic catalyst for the alkylation of methylcyclohexanol with acetic anhydride due to its hierarchical porosity and high specific surface area. It was found that after 3 hours, $100 \%$ alkylation conversion was achieved using hypercrosslinked polyHIPE-MAP while non hypercrosslinked materials performed significantly worse demonstrating the advantage of the bimodal pore structure with facilitated mass transfer. ${ }^{59}$

In addition to hypercrosslinking styrene type polyHIPEs with an internal crosslinker, Friedel-Crafts reaction with an external crosslinker was used. Crosslinked STY / DVB polyHIPEs were used for hypercrosslinking using formaldehyde dimethyl acetal as the external crosslinker applying the knitting approach. This hypercrosslinking method resulted in polyHIPE monoliths with specific surface areas between up to $595 \mathrm{~m}^{2} / \mathrm{g}$. Due to their extremely hydrophobic surface, the hypercrosslinked STY / DVB polyHIPE materials have shown good absorption capacity for oils, and could be used for oil-spill cleaning. ${ }^{109}$

Knitting type hypercrosslinking was also used to synthesize porous carbon foams, which were produced by carbonizing the STY / DVB hypercrosslinked polyHIPEs. Dimethoxymethane was used as an external crosslinker for hypercrosslinking. It was found that the STY / DVB ratio of polyHIPE precursors is strongly influenced by char yield, micro pore volume and BET surface area of carbonized polyHIPEs. ${ }^{110}$

Silverstein et al. synthesized porous carbons with high specific surface areas and hierarchical porous structure by pyrolysis of hypercrosslinked VBC/DVB polyHIPEs. ${ }^{111}$ Hypercrosslinking generated new links which limited the degradation of polyHIPE morphology after pyrolysis. Surface areas of pyrolyzed hypercrosslinked polyHIPEs were as high as $553 \mathrm{~m}^{2} / \mathrm{g}$, which meant less than $40 \%$ reduction compared to precursor polymers. Hypercrosslinking via $\mathrm{FeCl}_{3}$ catalysis was further used to synthesize acrylonitrile-DVB polyHIPEs, which were used for pyrolysis to produce nitrogen- and oxygen-codoped car-
bo-polyHIPEs with interconnected macro pores and micro / mesoporous carbon skeleton. ${ }^{12}$ Such carbo-polyHIPE was applied as a solid-state support for Pt and $\mathrm{Ru}$ bimetal nanoparticles, which, in turn, demonstrated a remarkable electrocatalytic ability to methanol electrooxidation. The specific surface area of carbo-HIPE was increased to $417 \mathrm{~m}^{2} / \mathrm{g}$ after hypercrosslinking, which proved to be important for improving electrocatalytic performance. Silica particle stabilized polyDVB polyHIPE was used as a porous solid acid catalyst for the production of hydroxymethyl furfural from cellulose in the presence of 1-ethyl-3-methyl-imidazolium chloride. For comparison, basic polyDVB was prepared, grafted with a $-\mathrm{SO}_{3} \mathrm{H}$ sulfonation process, and PDVB-co-SS polyHIPE, which was also sulfonated. This polymer was then hypercrosslinked and used as a solid state catalyst which, in addition to the macro pores in its skeleton, also had micro pores and, consequently, high specific surface area. Large specific surface area of polyHIPE and super-strong acid sites have been found to be crucial for cellulose conversion. ${ }^{113}$ Sevšek et al. ${ }^{114}$ synthesized STY/DVB polyHIPE monoliths with high DVB content. The remaining vinyl groups of DVB in STY/DVB monoliths were used for post-polymerisation crosslinking using the radical initiator di-tert-butyl peroxide in toluene and acetonitrile. The surface area in both solvents was found to be much larger after hypercrosslinking (up to $355 \mathrm{~m}^{2} / \mathrm{g}$ ), and the nitrogen adsorption / desorption method showed an increase in the number of micro pores after hypercrosslinking, which coincides with an increase in specific surface area. Pyridine containing polyHIPE could be hypercrosslinked by the second stage radical crosslinking of remaining vinyl groups. ${ }^{115}$ For the purposes of solid state support for catalysts, vinyl pyridine-DVB polyHIPE was prepared. Pyridine ring nitrogen was used for further functionalization - for the $\mathrm{Cu}$ (II) coordinate linker. This functionalized polyHIPE has been used as a solid state support for catalysts for a cycloaddition click reaction. Post polymerisation radical treatment (using di-tert-butyl peroxide) increased the specific surface area and created a multi modal porous profile, which was crucial for the success of the cycloaddition reaction.

Hypercrosslinking was demonstrated also on nonstyrene-type polyHIPEs. Mezhoud et al. ${ }^{116}$ synthesized poly (2-hydroxyethyl methacrylate-co- $\mathrm{N}, \mathrm{N}$ '-methylenebisacrylamide) polyHIPE and functionalized it with allylamine and propargylamine to create free double bonds that were used for hypercrosslinking with di- or tetra-thiols via thiol-ene click reactions. After the treatment surface areas of up to $1500 \mathrm{~m}^{2} / \mathrm{g}$ ware measured. The monoliths were then used for Au-nanoparticle decorated catalytic support to reduce nitrophenol and Eosin Y.

Another similar method is described as in situ hypercrosslinking of GMA-based polyHIPEs with multifunctional amines, where the amino-epoxy reaction is running parallel to the polymerisation. The result is a highly porous material with surface areas up to $63 \mathrm{~m}^{2} / \mathrm{g}$ 
and with good accessibility of reactive sites, but this system has disadvantages in terms of HIPE stability. ${ }^{117}$

\section{Conclusion and Outlook}

Porous polymers in different formats e.g. particles, monoliths, membranes, have a wide range of application fields; in separation, catalysis, synthesis, purification, in biomedical fields as supports for cell and tissue cultivation etc. Control of pore geometry, interconnectivity and size is of utmost importance for the desired performance. Not only is the control to narrow the pore size distribution important but the possibility to create materials with bimodal and hierarchical pore size distribution is very desired. While there are many methods for creating macroporosity in polymers, either during the polymerisation or after, high internal phase emulsion templating offers easily scalable straightforward technique for the synthesis of polymers with spherical interconnected pores with micrometer dimensions and high pore volume. Polymerisation parameters, droplet phase volume share and surfactants are key factors deciding the final structure. While good control of macroporosity in polyHIPEs is possible, the introduction of meso and microporosity is less trivial. Addition of porogenic solvents into the continuous phase can induce meso and micro porosity however the prevalence of cauliflower-like morphology and increase of pore volume significantly decreases the mechanical properties and is therefore in many cases unpractical. On the other hand, the post polymerisation hypercrosslinking enables the creation of meso and microporosity in already formed macroporous polyHIPEs without sacrificing the mechanical properties or even improving them in many aspects. Improved accessibility of reactive sites in the interior of the bulk of the material, increased surface area and wide solvent compatibility are further advantages of hypercrosslinked polyHIPEs. It is therefore expected that such materials with bimodal and hierarchical pore distribution will play an increasingly important role in various application fields in the future.

\section{List of abbreviations used}

$\begin{array}{ll}\text { BCMBP } & \text { 4,4'-bis(chloromethyl)biphenyl } \\ \text { BET } & \text { Brunauer-Emmett-Teller } \\ \text { DCE } & \text { dichloroethane } \\ \text { DCX } & \text { dichloroxylene } \\ \text { DVB } & \text { divinylbenzene } \\ \text { FDA } & \text { formaldehyde dimethyl acetal } \\ \text { GMA } & \text { glycidyl methacrylate } \\ \text { HIPE } & \text { high internal phase emulsion } \\ \text { MAP } & \text { 4-(N-methylamino)pyridine } \\ \text { NiPAAm } & \text { N-isopropyl acrylamide } \\ \text { PS } & \text { polystyrene }\end{array}$

$\begin{array}{ll}\text { STY } & \text { styrene } \\ \text { SS } & \text { sodium p-styrene sulfonate } \\ \text { VBC } & \text { vinylbenzyl chloride }\end{array}$

\section{Author biographies}

Amadeja Koler is a PhD student in PolyOrgLab at the Faculty of Chemistry and Chemical Engineering, University of Maribor. She studies the preparation of multi-level porous macromolecules. Her research includes the introduction of new reagents for controlled RAFT polymerization as well as colloidal precursor methods for formation od macroporosity and incorporation of hypercrosslinking for microporosity in macroporous materials.

Irena Pulko is a professor of chemistry of materials at the Faculty of Polymer Technology in Slovenj Gradec. She studied for PhD in the PolyOrgLab and in the research groups of Prof. Neil Cameron at Durham University and Prof. Christian Slugove at Graz University of Technology. Her research includes porous materials and polymer-based materials from renewable resources.

Peter Krajnc runs PolyOrgLab at the Faculty of Chemistry and Chemical Engineering, University of Maribor and is the vice dean at the faculty. He did his $\mathrm{PhD}$ in the group of Prof. Marko Zupan at the Faculty of Chemistry and Chemical Technology of the University of Ljubljana. He was a Marie Curie Fellow at the Department of Chemistry, Durham University with Prof. Neil Cameron. His main research interests are synthesis and applications of multi-level porous polymer-based materials.

\section{References}

1 A. Wilkinson, A. McNaught, Compendium Of Chemical Terminology ("Gold Book"), Blackwell Scientific Publications, Oxford, UK, 1997.

2 M. S. Silverstein, Polymer 2014, 55, 304-320.

DOI:10.1016/j.polymer.2013.08.068

3 M. S. Silverstein, Polymer 2017, 126, 261-282.

DOI:10.1016/j.polymer.2017.07.046

4 Y. Huang, S. H. Kim, L. R. Arriaga, Adv. Colloid Interface Sci. 2017, 247, 413-425. DOI:10.1016/j.cis.2017.07.013

5 B. F. B. Silva, C. Rodríguez-Abreu, N. Vilanova, Curr. Opin. Colloid Interface Sci. 2016, 25, 98-108.

DOI:10.1016/j.cocis.2016.07.006

6 N. R. Cameron, Polymer 2005, 46, 1439-1449.

DOI:10.1016/j.polymer.2004.11.097

7 I. Pulko, P. Krajnc, Encycl. Polym. Sci. Technol. 2017, 1-28. DOI:10.1002/0471440264.pst653

8 S. Torquato, T. M. Truskett, P. G. Debenedetti, Phys. Rev. Lett. 2000, 84, 2064-2067.

DOI:10.1103/PhysRevLett.84.2064 
9 D. Barby and Z. Haq, Low Density Porous Cross-Linked Polymeric Material Sand Their Preparation, 1986, EP Pat 60138.

10 S. Kovačič, D. Štefanec, P. Krajnc, Macromolecules 2007, 40, 8056-8060. DOI:10.1021/ma071380c

11 I. Pulko, P. Krajnc, Macromol. Rapid Commun. 2012, 33, 1731-46. DOI:10.1002/marc.201200393

12 E. Kot, N. Shirshova, A. Bismarck, J. H. G. Steinke, RSC Adv. 2014, 4, 11512-11519. DOI:10.1039/C4RA00118D

13 P. Krajnc, D. Štefanec, I. Pulko, Macromol. Rapid Commun. 2005, 26, 1289-1293. DOI:10.1002/marc.200500353

14 S. Kovačič, D. Štefanec, P. Krajnc, Macromolecules 2007, 40, 8056-8060. DOI:10.1021/ma071380c

15 J. Majer, M. Paljevac, E. Žagar, S. Kovačič, P. Krajnc, React. Funct. Polym. 2016, 109, 99-103.

DOI:10.1016/j.reactfunctpolym.2016.10.008

16 M. Paljevac, K. Jeřabek, P. Krajnc, J. Polym. Environ. 2012, 20, 1095-1102. DOI:10.1007/s10924-012-0524-4

17 O. Kulygin, M. S. Silverstein, Soft Matter 2007, 3, 1525-1529. DOI:10.1039/b711610a

18 M. Ovadia, M. S. Silverstein, Polym. Int. 2016, 65, 280-289. DOI:10.1002/pi.5052

19 B. H. L. Oh, A. Bismarck, M. B. Chan-Park, J. Mater. Chem. B 2015, 3, 4118-4122. DOI:10.1039/C5TB00303B

20 N. C. Grant, A. I. Cooper, H. Zhang, ASC Appl. Mater. Interface 2010, 2, 1400-1406. DOI:10.1021/am100049r

21 R. Butler, I. Hopkinson, A. I. Cooper, J. Am. Chem. Soc. 2003, 125, 14473-14481. DOI:10.1021/ja037570u

22 F. Audouin, M. Birot, E. Pasquinet, O. Besnard, P. Palmas, D. Poullain, H. Deleuze, Macromolecules 2011, 44, 4879-4886. DOI:10.1021/ma200861j

23 C. Youssef, R. Backov, M. Treguer, M. Birot, H. Deleuze, J. Polym. Sci. Pt A Polym. Chem. 2010, 48, 2942-2947. DOI:10.1002/pola.24075

24 D. Golub, P. Krajnc, React. Funct. Polym. 2020, 149, 104515104526. DOI:10.1016/j.reactfunctpolym.2020.104515

25 M. Sušec, S. C. Ligon, J. Stampfl, R. Liska, P. Krajnc, Macromol. Rapid Commun. 2013, 34, 938-943.

DOI:10.1002/marc.201300016

26 D. W. Johnson, C. Sherborne, M. P. Didsbury, C. Pateman, N. R. Cameron, F. Claeyssens, Adv. Mater. 2013, 25, 31773177. DOI:10.1002/adma.201370154

27 C. E. Hoyle, C. N. Bowman, Polym. Chem. 2010, 49, 15401573. DOI:10.1002/anie.200903924

28 A. Galperin, K. Smith, N. S. Geisler, J. D. Bryers, B. D. Ratner, ACS Biomater. Sci. 2015, 1, 593-600.

DOI:10.1021/acsbiomaterials.5b00133

29 H. B. Ly, L. Halbardier, D. Grande, Macromol. Symp. 2016, 365, 49-58. DOI:10.1002/masy.201650013

30 R. B. Diego, M. P. Olmedilla, A. S. Aroca, J. L. G. Ribelles, M. M. Pradas, G. G. Ferrer, M. S. Sanchez, J. Mater. Sci. 2005, 40, 4881-4887. DOI:10.1007/s10853-005-3885-4

31 T. J. Long, C. C. Sprenger, S. R. Plymate, B. D. Ratner, Biomaterials 2014, 35, 8164-8174.

DOI:10.1016/j.biomaterials.2014.04.090

32 M. Paljevac, L. Gradišnik, S. Lipovšek, U. Maver, J. Kotek, P. Krajnc, Macromol. Biosci. 2018, 18, 1-8.
DOI:10.1002/mabi.201870003

33 N. Bhardwaj, S. C. Kundu, Biotechnol. Adv. 2010, 28, 325347. DOI:10.1016/j.biotechadv.2010.01.004

34 L. Wang, A. J. Ryan, Electrospinning Tissue Regen. 2011, 3-33. DOI:10.1533/9780857092915.1.3

35 A. Samanta, B. Nandan, R. K. Srivastava, J. Colloid Interface Sci. 2016, 471, 29-36. DOI:10.1016/j.jcis.2016.03.012

36 B. A. Dikici, S. Dikici, G. C. Reilly, S. MacNeil, F. Claeyssens, Materials. 2019, 12, 2643-2667. DOI:10.3390/ma12162643

37 N. R. Cameron, A. Barbetta, J. Mater. Chem. 2000, 10, $2466-$ 2471. DOI:10.1039/b003596n

38 J. M. Williams, A. J. Gray, M. H. Wilkerson, Langmuir 1990, 6, 437-444. DOI:10.1021/la00092a026

39 D. C. Sherrington, P. Hodge, Synthesis Separations Using Functional Polymers, Wiley-VCH Verlag GmbH\&Co. KGaA, 1988.

40 A. Barbetta, N. R. Cameron, Macromolecules 2004, 37, 3202-3213. DOI:10.1021/ma035944y

41 S. Huš, M. Kolar, P. Krajnc, J. Chromatogr. A 2016, 1437, 168-175. DOI:10.1016/j.chroma.2016.02.012

42 P. Krajnc, N. Leber, D. Štefanec, S. Kontrec, A. Podgornik, J. Chromatogr. A 2005, 1065, 69-73.

DOI:10.1016/j.chroma.2004.10.051

43 S. Jerenec, M. Šimić, A. Savnik, A. Podgornik, M. Kolar, M. Turnšek, P. Krajnc, React. Funct. Polym. 2014, 78, 32-37. DOI:10.1016/j.reactfunctpolym.2014.02.011

44 M. Tebboth, A. Menner, A. Kogelbauer, A. Bismarck, Curr. Opin. Chem. Eng. 2014, 4, 114-120.

DOI:10.1016/j.coche.2014.03.001

45 J. Pribyl, B. Fletcher, W. Steckle, K. Taylor-Pashow, T. Shehee, B. Benicewicz, Anal. Chem. 2017, 89, 5174-5178. DOI:10.1021/acs.analchem.7b01153

46 K. M. L. Taylor-Pashow, J. G. Pribyl, Solvent Extr. Ion Exch. 2019, 37, 1-26. DOI:10.1080/07366299.2019.1592924

47 D. Yin, Y. Guan, H. Gu, Y. Jia, Q. Zhang, RSC Adv. 2017, 7, 7303-7309. DOI:10.1039/C6RA27609A

48 J. Majer, P. Kranjc, Macromol. Symp. 2010, 296, 5-10. DOI:10.1002/masy.201051002

49 J. M. Hughes, P. M. Budd, K. Tiede, J. Lewis, J. Apply. Polym. Sci. 2014, 132, 41229-41237. DOI:10.1002/app.41229

50 S. Choudhury, L. Fitzhenry, B. White, D. Connolly, Materials. 2016, 9, 1-14. DOI:10.3390/ma9030212

51 V. A. Davankov, M. P. Tsyurupa, React. Polym. 1990, 13, 27-42. DOI:10.1016/0923-1137(90)90038-6

52 M. P. Tsyurupa, V. A. Davankov, React. Funct. Polym. 2002, 53, 193-203. DOI:10.1016/S1381-5148(02)00173-6

53 O. Okay, Prog. Polym. Sci. 2000, 25, 711-779. DOI:10.1016/S0079-6700(00)00015-0

54 M. P. Tsyurupa, V. A. Davankov, React. Funct. Polym. 2006, 66, 768-779. DOI:10.1016/j.reactfunctpolym.2005.11.004

55 D. C. Sherrington, Chem. Commun. 1998, 2275-2286. DOI:10.1039/a803757d

56 K. Dušek, J. Polym. Sci. Part C Polym. Symp. 2010, 16, 12891299. DOI:10.1002/polc.5070160307

57 P. Veverka, K. Jeřábek, React. Funct. Polym. 2004, 59, 71-79. DOI:10.1016/j.reactfunctpolym.2003.12.008 
58 J. H. Ahn, J. E. Jang, C. G. Oh, S. K. Ihm, J. Cortez, D. C. Sherrington, Macromolecules 2006, 39, 627-632. DOI:10.1021/ma051152n

59 I. Pulko, J. Wall, P. Krajnc, N. R. Cameron, Chem. Eur. J. 2010, 16, 2350-2354. DOI:10.1002/chem.200903043

60 A. V. Pastukhov, M. P. Tsyurupa, V. A. Davankov, J. Polym. Sci. Pt B Polym. Phys. 1999, 37, 2324-2333.

DOI:10.1002/(SICI)1099-0488(19990901)37:17<2324:: AID-POLB4>3.0.CO;2-B

61 P. Veverka, K. Jeřábek, React. Funct. Polym. 1999, 41, 21-25. DOI:10.1016/S1381-5148(99)00030-9

62 V. A. Davankov, M. P. Tsyurupa, React. Polym. 1990, 13, 27-42. DOI:10.1016/0923-1137(90)90038-6

63 V. Davankov, V. Rogozhin, M. Tsyurupa, Macronet Polystyrene Structures for Ionites and Method of Producing Same, 1969, US Pat 3729457.

64 V. A. Davankov, S. V. Rogoshin, M. P. Tsyurupa, J Polym Sci Part C, Polym Symp 1974, 101, 95-101.

65 V. A. Davankov, G. I. Timofeeva, M. M. Ilyin, M. P. Tsyurupa, J. Polym. Sci. Part A Polym. Chem. 1997, 35, 3847-3852. DOI:10.1002/(SICI)1099-0518(199712)35:17<3847::AIDPOLA23>3.0.CO;2-C

66 V. Davankov, M. Tsyurupa, Compr. Anal. Chem. 2011, 56, 166-193. DOI:10.1016/S0166-526X(11)56006-4

67 M. P. Tsyurupa, Z. K. Blinnikova, Y. A. Davidovich, S. E. Lyubimov, A. V. Naumkin, V. A. Davankov, React. Funct. Polym. 2012, 72, 973-982.

DOI:10.1016/j.reactfunctpolym.2011.03.002

68 M. P. Tsyurupa, A. V. Pastukhov, V. A. Davankov, Dokl. Akad. Nauk 1997, 352, 2324-2333.

69 V. A. Davankov, M. M. Ilyin, M. P. Tsyurupa, G. I. Timofeeva, L. V. Dubrovina, Macromolecules 1996, 29, 8398-8403. DOI:10.1021/ma951673i

70 J. Hradil, E. Králová, Polymer 1998, 39, 6041-6048. DOI:10.1016/S0032-3861(98)00057-3

71 D. Zhang, L. Tao, J. Ju, Y. Wang, Q. Wang, T. Wang, Polymer 2015, 60, 234-240. DOI:10.1016/j.polymer.2015.01.053

72 F. Maya, F. Svec, Polymer 2014, 55, 340-346. DOI:10.1016/j.polymer.2013.08.018

73 T. Ratvijitvech, M. Barrow, A. I. Cooper, D. J. Adams, Polym. Chem. 2015, 6, 7280-7285. DOI:10.1039/C5PY00668F

74 L. Tan, B. Li, X. Yang, W. Wang, B. Tan, Polymer 2015, 70, 336-342. DOI:10.1016/j.polymer.2015.06.026

75 C. D. Wood, T. Bien, A. Trewin, N. Hongjun, D. Bradshaw, M. J. Rosseinsky, Y. Z. Khimyak, N. L. Campbell, R. Kirk, E. Stöckel, A. I. Cooper, Chem. Mater. 2007, 19, 2034-2048. DOI:10.1021/cm070356a

76 M. Ghafari, J. D. Atkinson, Polymer 2017, 116, 278-286. DOI:10.1016/j.polymer.2017.03.082

77 M. G. Schwab, I. Senkovska, M. Rose, N. Klein, M. Koch, J. Pahnke, G. Jonschker, B. Schmitz, M. Hirscher, S. Kaskel, Soft Matter 2009, 5, 1055-1059.

DOI:10.1039/b815143a

78 Y. Yang, B. Tan, C. D. Wood, J. Mater. Chem. A 2016, 4, 15072-15080. DOI:10.1039/C6TA05226F

79 Q. Liu, B. Xia, J. Huang, B. Liao, H. Liu, B. Ou, L. Chen, Z.
Zhou, Mater. Chem. Phys. 2017, 199, 616-622. DOI:10.1016/j.matchemphys.2017.07.032

80 L. D. Belyakova, T. I. Schevchenko, V. A. Davankov, M. P. Tsyurupa, Adv. Colloid Interface Sci. 1986, 25, 249-266.

DOI:10.1016/0001-8686(86)80011-2

81 M. P. Tsyurupa, L. A. Maslova, A. I. Andreeva, T. A. Mrachkovskaya, V. A. Davankov, React. Polym. 1995, 25, 69-78. DOI:10.1016/0923-1137(95)00021-A

82 N. A. Penner, P. N. Nesterenko, M. M. Hyin, M. P. Tsyurupa, V. A. Davankov, Chromatographia 1999, 50, 611-620. DOI:10.1007/BF02493669

83 V. Davankov, M. Tsyurupa, M. Ilyin, L. Pavlova, J. Chromatogr. A 2002, 965, 65-73. DOI:10.1016/S0021-9673(01)01583-7

84 V. A. Davankov, C. S. Sychov, M. M. Ilyin, K. O. Sochilina, J. Chromatogr. A 2003, 987, 67-75. DOI:10.1016/S0021-9673(02)01914-3

85 V. Davankov, L. Pavlova, M. Tsyurupa, J. Brady, M. Balsamo, E. Yousha, J. Chromatogr. B Biomed. Sci. Appl. 2000, 739, 73-80. DOI:10.1016/S0378-4347(99)00554-X

86 B. Li, R. Gong, Y. Luo, B. Tan, Soft Matter 2011, 7, 1091010916. DOI:10.1039/c1sm06113e

87 J. Urban, F. Svec, J. M. J. Fréchet, J. Chromatogr. A 2010, 1217, 8212-8221. DOI:10.1016/j.chroma.2010.10.100

88 J. Urban, F. Svec, J. M. J. Fréchet, Anal. Chem. 2010, 82, 1621-1623. DOI:10.1021/ac100008n

89 Y. Lv, Z. Lin, F. Svec, Anal. Chem. 2012, 84, 8457-8460. DOI:10.1021/ac302438m

90 X. J. Chen, N. P. Dinh, J. Zhao, Y. T. Wang, S. P. Li, F. Svec, J. Sep. Sci. 2012, 35, 1502-1505. DOI:10.1002/jssc.201200138

91 F. Maya, F. Svec, J. Chromatogr. A 2013, 1317, 32-38. DOI:10.1016/j.chroma.2013.07.073

92 Z. K. Blinnikova, I. R. Golding, M. P. Tsyurupa, A. A. Fomkin, A. L. Pulin, V. A. Davankov, Polym. Sci. - Ser. B 2018, 60, 91-98. DOI:10.1134/S1560090418010013

93 C. D. Wood, B. Tan, A. Trewin, F. Su, M. J. Rosseinsky, D. Bradshaw, Y. Sun, L. Zhou, A. I. Cooper, Adv. Mater. 2008, 20, 1916-1921. DOI:10.1002/adma.200702397

94 J. Germain, J. M. J. Fréchet, F. Svec, Chem. Commun. 2009, 1526-1528. DOI:10.1039/b821233c

95 M. G. Schwab, A. Lennert, J. Pahnke, G. Jonschker, M. Koch, I. Senkovska, M. Rehahn, S. Kaskel, J. Mater. Chem. 2011, 21,2131-2135. DOI:10.1039/C0JM03017A

96 D. Chen, S. Gu, Y. Fu, Y. Zhu, C. Liu, G. Li, G. Yu, C. Pan, Polym. Chem. 2016, 7, 3416-3422. DOI:10.1039/C6PY00278A

97 R. Dawson, T. Ratvijitvech, M. Corker, A. Laybourn, Y. Z. Khimyak, A. I. Cooper, D. J. Adams, Polym. Chem. 2012, 3, 2034-2038. DOI:10.1039/c2py20136d

98 B. Li, R. Gong, W. Wang, X. Huang, W. Zhang, H. Li, C. Hu, B. Tan, Macromolecules 2011, 44, 2410-2414.

DOI:10.1021/ma200630s

99 L. Pan, Q. Chen, J.-H. Zhu, J.-G. Yu, Y.-J. He, B.-H. Han, Polym. Chem. 2015, 6, 2478-2487.

DOI:10.1039/C4PY01797H

100 X. Yang, M. Yu, Y. Zhao, C. Zhang, X. Wang, J. X. Jiang, RSC 
Adv. 2014, 4, 61051-61055. DOI:10.1039/C4RA09394A

101 J. Germain, F. Svec, J. M. J. Fre' chet, Chem. Mater. 2008, 20, 7069-7076. DOI:10.1021/cm802157r

102 Y. Luo, S. Zhang, Y. Ma, W. Wang, B. Tan, Polym. Chem. 2013, 4, 1126-1131. DOI:10.1039/C2PY20914D

103 M. L. Errahali M., Gatti G., Tei L., Paul G., Rolla G. A., Canti L., Fraccarollo A., Cossi M., Comotti A., Sozzani P., J. Phys. Chem. 2014, 118, 28699-28710. DOI:10.1021/jp5096695

104 Y. Luo, B. Li, W. Wang, K. Wu, B. Tan, Adv. Mater. 2012, 24, 5703-5707. DOI:10.1002/adma.201202447

105 T. Ratvijitvech, M. Barrow, A. I. Cooper, D. J. Adams, Polym. Chem. 2015, 6, 7280-7285. DOI:10.1039/C5PY00668F

106 S. Yao, X. Yang, M. Yu, Y. Zhang, J. X. Jiang, J. Mater. Chem. A 2014, 2, 8054-8059. DOI:10.1039/C4TA00375F

107 R. Dawson, E. Stöckel, J. R. Holst, D. J. Adams, A. I. Cooper, Energy Environ. Sci. 2011, 4, 4239-4245. DOI:10.1039/clee01971f

108 L. Tan, B. Li, X. Yang, W. Wang, B. Tan, Polymer 2015, 70, 336-342. DOI:10.1016/j.polymer.2015.06.026

109 X. Yang, L. Tan, L. Xia, C. D. Wood, B. Tan, Macromol. Rapid Commun. 2005, 36, 1553-1558.

DOI:10.1002/marc.201500235
110 R. T. Woodward, A. Jobbe-Duval, S. Marchesini, D. B. Anthony, C. Petit, A. Bismarck, Polymer 2017, 115, 146-153. DOI:10.1016/j.polymer.2017.03.042

111 S. Israel, I. Gurevitch, M. S. Silverstein, Polymer 2015, 72, 453-463. DOI:10.1016/j.polymer.2015.02.055

112 F. Yi, Y. Gao, H. Li, L. Yi, D. Chen, S. Lu, Electrochim. Acta 2016, 211, 768-776. DOI:10.1016/j.electacta.2016.06.092

113 J. Pan, H. Gao, Y. Zhang, J. Zeng, W. Shi, C. Song, Y. Yan, L. Yu, D. Chang, RSC Adv. 2014, 4, 59175-59184. DOI:10.1039/C4RA10383A

114 U. Sevšek, J. Brus, K. Jeřabek, P. Krajnc, Polymer 2014, 55, 410-415. DOI:10.1016/j.polymer.2013.09.026

115 A. Koler, M. Paljevac, N. Cmager, J. Iskra, M. Kolar, P. Krajnc, Polymer 2017, 126, 402-407.

DOI:10.1016/j.polymer.2017.04.051

116 S. Mezhoud, M. Paljevac, A. Koler, B. Le Droumaguet, D. Grande, P. Krajnc, React. Funct. Polym. 2018, 132, 51-59. DOI:10.1016/j.reactfunctpolym.2018.09.009

117 J. Majer, E. Žagar, P. Krajnc, S. Kovačič, Colloid Polym. Sci. 2019, 297, 239-247. DOI:10.1007/s00396-018-4455-z

\section{Povzetek}

Poroznost $v$ polimerih in polimenih materialih je zelo pomembna, saj jim le ta daje posebne funkcionalnosti, kot so izboljšani prenos snovi skozi material, izboljšana dosegljivost reaktivnih mest, znižana skupna masa, prilagojene separacijske lastnosti, itd.. Razvoj na področju polimerov s kontrolirano morfologijo, kar se tiče velikosti in oblike por, povezovalnosti por in njihove porazdelitve velikosti pomembno vpliva na uporabnost teh polimerov na področju katalize, separacije, sinteze na trdni fazi, adsorpcije, senzorjev, biomedicinskih pripomočkov in mnogih drugih. Zlasti so zanimivi polimeri $\mathrm{z}$ izrazito bimodalno ali hierarhično porazdelitvijo por, saj to omogoča uporabo v aplikacijah, kjer so potrebne velikosti por na več ravneh. Emulzije lahko uporabimo za pripravo polimerov z vključenimi medsebojno povezanimi sferičnimi porami na mikrometrski ravni, medtem ko postpolimerizacijsko zamreženje vpliva na mikro poroznost. S kombinirano uporabo obeh tehnik dobimo materiale $\mathrm{z}$ večnivojsko in hierarhično poroznostjo $\mathrm{z}$ velikim potencialom uporabe.

Except when otherwise noted, articles in this journal are published under the terms and conditions of the Creative Commons Attribution 4.0 International License 